\title{
How quickly can Iran make a nuclear bomb?
}

With an international deal in jeopardy, Iran is not racing to build a nuclear weapon but its capabilities are growing again.

Iran has accumulated 1,200 kilograms of enriched uranium - more than doubling the stockpile it had just three months ago, according to a statement from a senior official at the Atomic Energy Organization of Iran on 25 January.

That's enough to build one atomic bomb, if the uranium is further refined to make it weapons-grade - a process that could take just two to three months, says David Albright, a nuclear-policy specialist at the Institute for Science and International Security in Washington DC. Building actual weapons would take much longer, he adds.

If confirmed, the rate of expansion of Iran's uranium stockpile "shifts things dramatically", Albright adds. But he and others say that there is no evidence that Iran is rushing to build a bomb - for now.

Tensions between Iran and the United States have been escalating. On 3 January, a US drone strike killed Qasem Soleimani, the architect of Iran's military involvement in the Middle East. In response, Iran shot missiles at US bases in Iraq.

The Joint Comprehensive Plan of Action (JCPOA), the 2015 deal between Iran and six global powers that limited its nuclear capabilities in exchange for the lifting of economic sanctions, is now in serious jeopardy. US President Donald Trump pulled out of the deal in May 2018, and Iran announced in May last year that it would resume uranium enrichment.

Nature talked to nuclear experts to find out how soon Iran could build a bomb, and whether this is likely to happen.

\section{Has Iran tried to build nuclear weapons before?}

Building nuclear weapons is expensive and requires technical expertise in enriching uranium. The fissionable isotope uranium-235, which makes up less than $1 \%$ of natural uranium, must be separated from uranium-238, which is by far the more common isotope. Iran has had an active nuclear programme for decades. The country has always maintained that this was purely for peaceful purposes, such as producing isotopes for medical use. But in the early 2000s, Iran seemed to have a programme to build at least five uranium fission bombs, according to US intelligence assessments and international observers.

Reports in the mid-2000s by the United Nations International Atomic Energy Agency (IAEA) suggested that Iran might have been actively working to build a nuclear arsenal. That would be a violation of the 1968 Treaty on the Non-Proliferation of Nuclear Weapons (NPT), which Iran has signed. In 2003, bowing to international pressure, the country agreed to cut down its nuclear activities drastically but not completely.

\section{Did the 2015 deal reduce Iran's nuclear capabilities?}

By 2015 , the country had stockpiled 11 tonnes of uranium hexafluoride enriched to as much as $20 \%{ }^{235} \mathrm{U}$ - weapons-grade uranium must be enriched to $90 \%$. Uranium hexafluoride in processed in for enrichment in gas form, in high-speed centrifuges, and in 2015 Iran had more than 10,000 of these centrifuges. When the JCPOA was signed in July that year, experts estimated that the country was months - perhaps weeks - away from producing weapons-grade uranium.

But the JCPOA forced Iran to ship most of its stockpile abroad, and to mothball the majority of its centrifuges. The aim was partly to stretch the time Iran needed to stockpile enough fissile material for a bomb - known as 'breakout time' - to at least a year. The deal also subjected Iran to a stringent regime of IAEA inspections.

\section{What was the impact of the US withdrawal from the nuclear deal?}

Seyed Hossein Mousavian, who was a

\section{"Tensions between Iran and the United States have been escalating."}

spokesperson for Iran's nuclear negotiating team in 2003, says that Iranians feel cheated. The perception in the country is that "you cannot negotiate with or trust the US", says Mousavian, now a nuclear-policy specialist at Princeton University in New Jersey.

Does Iran now have enough enriched uranium to build nuclear bombs? Last November, the IAEA found that Iran had accumulated around 550 kilograms of uranium hexafluoride that was

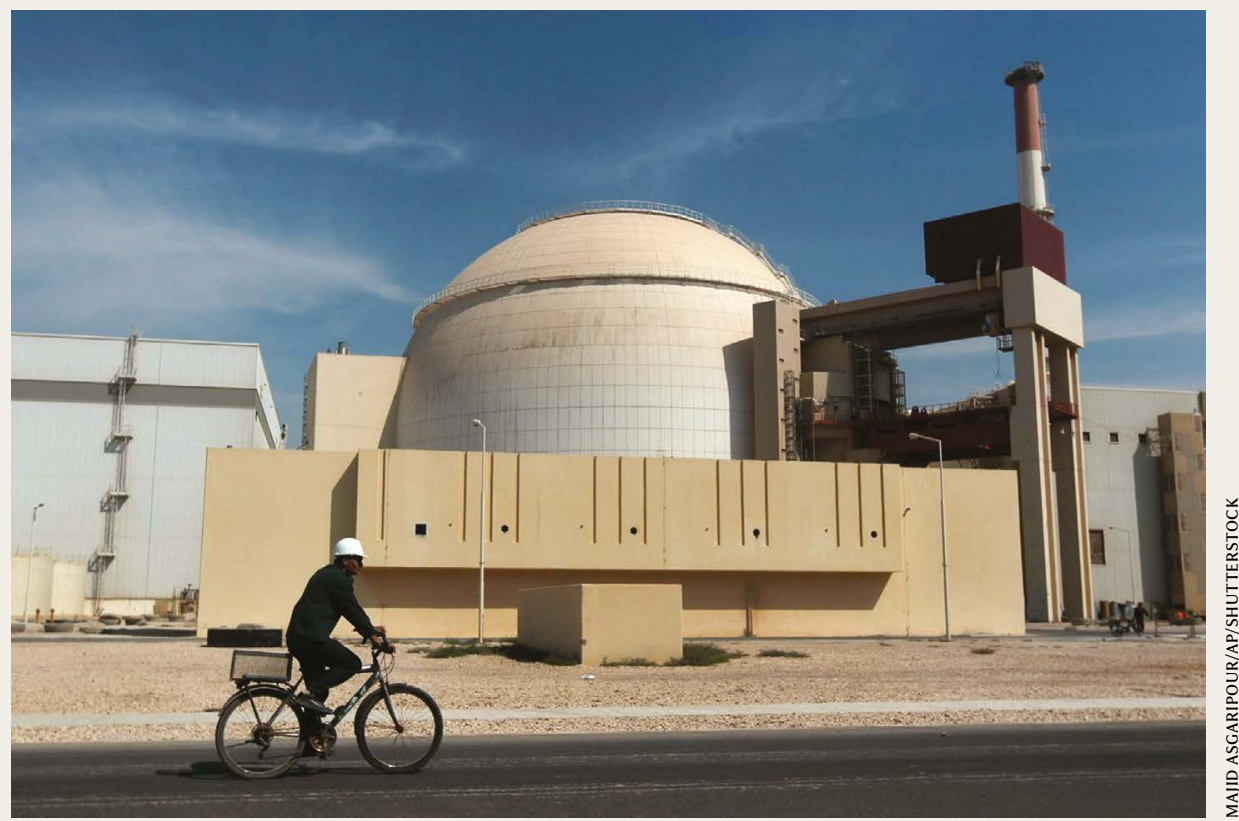

Iran's Bushehr nuclear power plant has been in operation for almost ten years. 
"moderately enriched" to less than $4.5 \%$ ${ }^{235} \mathrm{U}$. It is unclear what material the Iranian official was referring to in his 25 January claim, but it is presumed to be 1,200 kilograms of moderately enriched uranium hexafluoride. If further enriched, this could yield more than 30 kilograms of weaponsgrade uranium, enough to build one fission bomb.

How quickly could Iran make a bomb once it has enough weapons-grade uranium? Possessing fissile material is not enough: a country also has to master the design and manufacture of a bomb. In particular, uranium hexafluoride must be converted to uranium metal, which is not straightforward, says Richard Johnson, a proliferation specialist at the Nuclear Threat Initiative, a policy research centre in Washington DC. According to Albright, some intelligence agencies estimate that it could take Iran about two years to make its first two bombs if it wanted to do this.

If the nuclear deal is scrapped, will Iran be legally entitled to go nuclear?

No. Because Iran has signed the NPT, it is committed to using nuclear technology exclusively for peaceful purposes.

Members of the NPT must allow the

IAEA to verify their compliance, or face consequences. But Iran could withdraw from the NPT, as North Korea did in 2003, as it was becoming a nuclear power. Iranian foreign minister Mohammad Javad Zarif said on 20 January that the country is prepared to withdraw if its continued enrichment programme is reported to the UN Security Council.

\section{So is Iran actively working towards a} nuclear bomb?

"All the signs are that they are not," says Zia Mian, a physicist and nuclear-policy expert at Princeton University. The country has complied with the rigorous IAEA inspection regime set out in the JCPOA. This means that a nuclear-weapons programme is "either hidden so well that no one has been able to find it so far, or that there is no such crash programme", he says. Albright agrees, saying that Iran could be stockpiling enriched uranium to increase its leverage in future negotiations. "You don't see some of the indicators that would imply a well worked-out decision" to actually build bombs, he says. But expanding stockpiles of enriched uranium brings the country closer to being able to make a nuclear bomb - if it wishes.

By Davide Castelvecchi

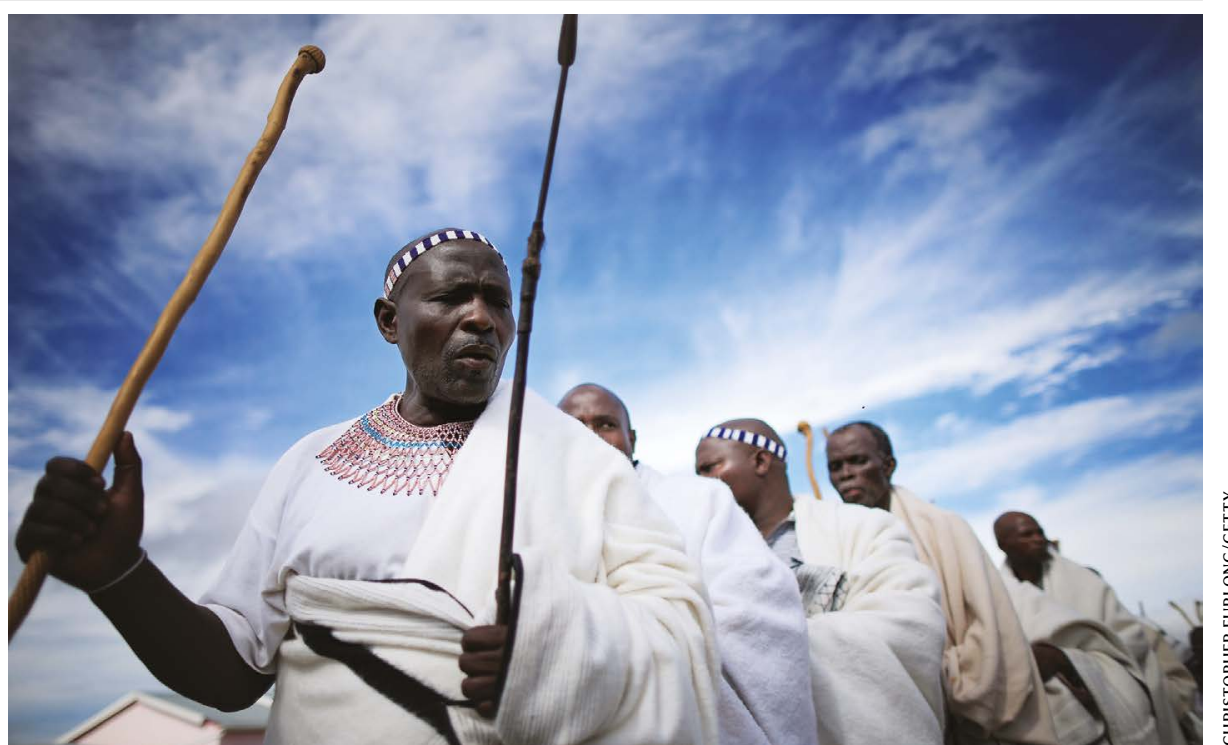

The Xhosa people have greater genetic diversity than do people of non-African descent.

\section{AFRICAN SCHIZOPHRENIA STUDYIDENTIFIES DAMAGINGMUTATIONS}

\section{Genetic studies of mental illness have largely been conducted in people with European ancestry.}

\section{By Alison Abbott}

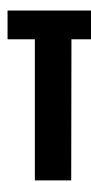
he first genomic analysis of schizophrenia in an African population has identified multiple rare mutations that occur more frequently in people with the condition.

The mutations are mainly in genes that are important for brain development and the brain's synapses, structures that coordinate communication between neurons. The findings, published on 31 January (S. Gulsuner et al. Science 367, 569-573; 2020), match those of other schizophrenia studies - but nearly all previous research has been conducted in European or Asian populations.

This research is important because Africa has represented a big gap in the populations that geneticists have studied, says psychiatric geneticist Andreas Meyer-Lindenberg, director of the Central Institute of Mental Health in Mannheim, Germany. He says that the work lends support to current hypotheses about the biological origins of schizophrenia, which can cause hallucinations and delusions. Researchers think that each mutation contributes a small amount to the overall risk of developing the condition, and that disruption to synapses could be crucial to the disease's development.

Geneticists have long been criticized for failing to sample diverse populations for genomic studies, which have largely neglected African people. “This urgently needs more attention," says Ambroise Wonkam, a human geneticist at the University of Cape Town, South Africa.

This bias means that diagnostic tests and treatments developed on the basis of these studies might not work in certain populations. But studies in diverse populations also allow researchers to build up a fuller picture of diseases. In particular, African people as a group have genomes that are more diverse than those of other populations because the vast majority of human evolution took place in Africa.

The study enrolled around 900 people with schizophrenia and a similar number of controls. All identified as Xhosa, members of an ethnic group who live mainly in South Africa.

The researchers sequenced the participants' genomes and searched for mutations that damage genes. Such mutations were much more prevalent in people with schizophrenia than in the control individuals, and were concentrated in genes that are highly expressed in the brain or involved in synapse function.

The results echo those of a large Swedish study (G. Genovese et al. Nature Neurosci. 19, 1433-1441;2016) that used the same methods, but the density of mutations in affected genes were generally larger in the Xhosa participants. The authors say that this reflects the greater genetic variation among Xhosa people. 